Reviews

\title{
Marx and the Postmodernism Debates: An Agenda for Critical Theory by Lorraine Y. Landry. London: Praeger Publishers (2000), xiii+232pp.
}

\section{Reviewed by Douglas J. Cremer, Department of Natural and Social Sciences, Woodbury University, Burbank, CA.}

\begin{abstract}
Lorraine Landry has confidently entered a field that has drawn much attention among philosophers: the debate between Jürgen Habermas on the one hand and Jacques Derrida, Michel Foucault, and Jean-François Lyotard on the other. Rather than seeing this intersection as one between a rationalist modernism and an irrationalist postmodernism, Landry seeks to create what she calls a "fruitful tension" between these two warring camps by reconceptualizing the debate through the work of Karl Marx. The connection between Marx and Habermas is clear. Habermas, as the heir to Theodor Adorno and Max Horkheimer, is recognized as the latest German philosopher to build off of Marx' work. That a rapprochement between these two positions might be accomplished through the work of Marx has also been hinted at in Derrida's later works as well as in the widely know early Marxian roots of Lyotard and Foucault. Landry makes profitable use of a wide variety of well-known commentators on the debates, among them Seyla Benhabib, Matei Calinescu, Mike Featherstone, Douglas Kellner, Andreas Huyssen, Alex Callinicos, Christopher Norris, Thomas McCarthy, Peter Dews, and David Rasmussen. Due to the wide range of material covered and the clarity of writing, Marx and the Postmodernism Debates is a welcome addition to this highly developed, intellectually rich and philosophically challenging literature, doing an admirable job of summarizing the major issues and developing a new approach that keeps the book from being another rehash of a now lengthy debate.

By explicitly reintroducing Marx to the debates, Landry hopes to show the relevancy of postmodern thought for social change and contemporary politics, making it part of the tradition of ideology critiques begun by Marx. Yet before undertaking this project, Landry goes back to the work of Immanuel Kant, who is as important as Marx in her overall analysis. It is in Kant's work that Landry sees the fully developed form of modernity: individualist, instrumental, mechanical, methodological, and manipulative. Yet this modernity, she argues, was from its origins tied to and complicated by the earlier existing organic conception of the world as well as the emerging romantic view. Landry makes the argument that there are thus as many modernisms as there are postmodernisms, as many different forms of Enlightenment rationalism as there are postmodern critiques. Her analysis of aesthetic modernism, as a variant within modern thought that was intensely critical of the rationalist strain of modernism, is well argued. It is one of the cornerstones of her effort to show how the paradoxes and complexities of postmodernity were embedded in the paradoxes and complexities of modernity. One of the strengths of this book is the clear way Landry lays out these important issues.

The apparent conflict between modernity and postmodernity is repositioned by Landry as a "fruitful tension," a phrase she admits is a bit trite. Her stated methodology is to take the positions of Habermas, Derrida, Foucault and Lyotard each on its own terms and as empathetically as possible, referring to similarities and differences, avoiding, easy syntheses and polemics, and seeking a viable theory and politics from each. She initially addresses Habermas' critique of postmodernism where he argues that postmodernism is neo-conservative, irrational and potentially fascist. Detailing Habermas' rejection of the aesthetic modernism at the root of postmodernism, Landry discusses Habermas' associated dismissal of the outsider view taken by the tradition from Friedrich Nietzsche through Martin Heidegger to Derrida and Foucault. She offers that Habermas was mistaken to take aesthetic postmodernism as a natural ally to political conservatism. It is precisely in the fact that both critical theory and postmodernism seek a critique of late twentieth century modernity, and that both have taken reified, and thus amendable, views of the complexities of modernity, that Landry sees the possibility of rapprochement, of creating a fruitful tension.

The chapters on Derrida and Foucault are clear and concise summations of their positions and of their defenses against the attacks launched by Habermas. If there is a fault here, it is that Landry's voice is often lost amid all the commentators and philosophers, to the point that it is sometimes unclear exactly who is speaking in any one part of the text. Landry's goal is to emphasize the rootedness of postmodernism in modernist aesthetics, especially in Kant's third critique, the Critique of Judgement. It is this Kantian connection that is key to Landry's effort to rehabilitate postmodernism in the light of its confrontation with critical theory. In a Kantian light, Landry sees deconstruction as a form of ideology critique converging with the tradition of Adorno and Habermas. Foucault's genealogy is also placed within a Kantian framework, recasting Foucault's essay on the Enlightenment as a defense
\end{abstract}


Reviews

of the spirit of inquiry against deadening principles and the promotion of an aesthetic of existence. For Landry, Foucault's practical ethics, along with Derrida's deconstruction, recognizes the inescapability of reason but does not accept its absoluteness.

If there is one unreachable postmodernist in this group for Landry, it is Lyotard. His aesthetic postmodernism, which rejects the connection between political theory and practical politics, is less likely to produce anything of value in fruitful tension with critical theory, according to Landry. Although Lyotard is the central catalyst in the fractious discussion between Habermas and postmodernism, he tends to drop out of the discussion after Landry's critique in the fifth chapter. This is a weakness in the work, for Lyotard, along with other French theorists such as Jean Baudrillard, appear to be among the most intractable of the postmodernists as far as critical theory is concerned. By effectively limiting the discussion of postmodernism to its poststructuralist adherents in Derrida and Foucault, Landry makes her efforts easier, but also less significant. The tensions within postmodernism between the intense critiques of consumer society and of the oppression of institutionalized knowledge on the one hand and the celebration of image, virtual reality, and computerized data banks on the other, are obscured by the perspective Landry chooses.

The result is an emphasis on the postmodernism debates as a twentieth century extension of the differences between the Kant of the first two critiques, refracted through G. W. F. Hegel and Marx, and the Kant of the third critique, developed by the work of Nietzsche and Heidegger. Landry wants to remind us again of the complexity of modern thought, of an Enlightenment tradition that embraces rational, moral, and aesthetic critiques. She rightly desires to keep us away from the simplicity of the so-called "Enlightenment Project" with its tendencies towards intellectual repression and political terror. She effectively takes us away from the stale dichotomy between transcendental rationalism and nihilistic relativism towards sustaining the tension between the Nietzsche-Heidegger tradition and the Hegel-Marx tradition. Finally, Landry tries to preserve the postmodern awareness of the multiplicity of otherness and to emancipate modernism from the domineering universality of the subject by using Kant as the touchstone.

Much more critical of Habermas than of Derrida or Foucault, Landry accuses the German philosopher of failing to see that his theory of communicative action does not hew to either a correspondence notion of truth nor to a purely realist epistemology. For Landry, a nonfoundationalist, antirealist philosophy can establish the ground for the intended reconciliation of postmodernism and critical theory and for a progressive political theory, including Habermas' goals of completing modernity and avoiding the political linkage between postmodernism and neoconservatism. Habermas, according to Landry, misses the importance of language in Marx' writing, making Marx bound to the philosophy of the subject than to ideology critique and the analysis of class conflict. Similarly, postmodernism's misinterpretation of Marx as focused on production, wedded to materialist thought and realist philosophy, is also taken to task, but Landry's fire is directed mostly at Habermas. The detailed critique of Habermas' position is not matched by an equally thorough critique of poststructuralist or postmodernist concerns. After outlining and debunking the Habermassian and postmodernist critiques of Marx, Landry finally makes her case for the rehabilitation of Marxian critical theory in a postmodern context. Landry's Marx is an advocate for situated knowledge, much like the postmodernists, a still important voice for critical theory and radical politics. Furthermore, Marx is seen, as are all the others, through a Kantian lens, emphasizing the critique of language and ideology. Landry wants to move beyond the negative evaluations of Marx towards a positive reception of Marx' refusal to be caught between the poles of universal reason and relativist skepticism. The rejection of simple bipolar dichotomies, a common denominator among postmodernists, is characteristic of Landry's thought as well, illustrating once again her closer affinity to Derrida and Foucault than to Habermas in the postmodernism debates.

Ultimately, Landry wants to argue that a limited, pragmatic transcendence can be sustained by deconstructing textual play, that a marriage of critical theory and postmodernism can be made. She opens the door wide for a consideration of this as a possibility, but does not firmly make the case that it can be accomplished. For a book that perhaps could have been alternately titled "Kant, Critical Theory, and Poststructuralism," Landry does a fine job in establishing the conditions for the possibility of a rapprochement between critical theory and certain forms of postmodernism. Rather than using Marx to reinterpret the postmodernism debates, as the actual title might imply, Landry has shown how postmodernist concerns over difference, the Other, and the uses of language can possibly rehabilitate Marx, and through him, critical theory. 